\title{
Influence of Coarse Aggregate Gradation on the Mechnical Properties of Concrete, Part II: No-Fines Vs. Ordinary Concrete
}

\author{
Abdul Salam Buller \\ Department of Civil Engineering, \\ Quaid-e-Awam University of Engineering, Science \& \\ Technology, Larkana Campus, Sindh, Pakistan \\ buller.salam@quest.edu.pk
}

\author{
Zaheer Ahmed Tunio \\ Department of Civil Engineering, \\ Quaid-e-Awam University of Engineering, Science \& \\ Technology, Nawabshah, Sindh, Pakistan \\ zaheerahmedtunio@gmail.com
}

\author{
Fahad-ul-Rehman Abro \\ Department of Civil Engineering, \\ Mehran University of Engineering and \\ Technology, \\ Jamshoro, Sindh, Pakistan \\ fahad.abro@gmail.com
}

\author{
Tariq Ali \\ Department of Civil Engineering, \\ Quaid-e-Awam University of \\ Engineering, Science \& Technology, \\ Nawabshah, Sindh, Pakistan \\ tariqdehraj@gmail.com
}

\author{
Karam Ali Jamali \\ Department of Civil Engineering, \\ Quaid-e-Awam University of \\ Engineering, Science \& Technology, \\ Nawabshah, Sindh, Pakistan \\ tespublic@yahoo.com
}

\begin{abstract}
This study aims to investigate the effect of different gradations of coarse aggregates on mechanical properties of nofines concrete (NFC). NFC reduces a structure's self-weight, thus minimizing cost. The effects of coarse aggregate gradation on mechanical properties such as compressive strength, split tensile strength, and flexural strength were studied and compared at the end of 28-day water curing. A fixed cement- to-aggregate proportion 1:6 with 0.5 water/cement $(w / c)$ ratio was adopted. Four gradations of coarse aggregates ranging between specific maximum and minimum size were used, namely $5 \mathrm{~mm}-4 \mathrm{~mm}$, $10 \mathrm{~mm}-4 \mathrm{~mm}, 20 \mathrm{~mm}-4 \mathrm{~mm}$ and $20 \mathrm{~mm}-15 \mathrm{~mm}$. The results of this study reveal the substantial effect of the gradation of coarse aggregates on strength properties compressive and tensile strength of NFC.
\end{abstract}

Keywords-no-fines;aggregate graddation;cement to agggregate proportion;compressive strength;texture

\section{INTRODUCTION}

Concrete without fines is a type of lightweight porous concrete acquired by removing the sand from the ordinary concrete mix. It is a material of two phases, rough aggregates, surrounded by a thin layer of cement paste without fine aggregates. NFC is a type of lightweight concrete produced from only cement water and coarse aggregates. The coarse aggregates are covered with cement paste and linked point-topoint with thin cement paste holding aggregates in a matrix, augmenting concrete strength. It is recognized that self-weight constitutes a very big percentage of the complete structure load in concrete buildings. There are significant benefits in decreasing the concrete unit weight. Appropriate resistance of structural light weight aggregate concrete (LWAC) is now prevalent in use. In frame structures, the petition walls are free of charge where the construction of these non-structural elements with low-strength lightweight concrete would result in a subsequent reduction in the overall weight of the structure. NFC has many applications, [1-13], described in Part I [14]. Civil engineers have been challenged to transform waste into helpful building materials $[13,15]$ and large quantities of raw materials and waste, in particular demolition waste, are used as recycled aggregates for the construction and use of nonfinished concrete waste, making it more economical compared to standard concrete [16, 17]. NFC is an environmentally friendly paving material because it has much higher voids in its body than those of normal concrete resulting in rainwater runoff from it [11]. NFC's cement/aggregate ratio usually varies from 1:6 to $1: 10$ and aggregate is usually used from $20 \mathrm{~mm}$ to $10 \mathrm{~mm}[14,16]$ and the proportion of water to cement ranges from 0.28 to 0.40 [18]. No concrete fines normally used are single sized coarse aggregates. This resulted to the concept of carrying out an experimental study to explore the impact of various gradations of coarse aggregates used in concrete nofines in the first Part [14]. In this Part, the impact of coarse aggregates' size have been researched regarding mechanical characteristics. Compressive and tensile strength tests were performed in samples cast from four distinct lots of coarse aggregates. The results of NFC were compared with that of conventional concrete.

\section{EXPERIMENTAL PROCEDURE}

The main aim of this study is to investigate unit weight, compressive strength, splitting tensile strength, and flexural strength of no-fines and ordinary concrete. Cement-aggregate (c-a) proportions 1:6 of NFC and 1:2:4 of ordinary concrete were adopted. Four different coarse aggregate gradations, 
namely $5 \mathrm{~mm}-4 \mathrm{~mm}, 10 \mathrm{~mm}-4 \mathrm{~mm}, 20 \mathrm{~mm}-4 \mathrm{~mm}$, and $20 \mathrm{~mm}-$ $15 \mathrm{~mm}$, were used. NFC and ordinary concrete were cast with $0.5 \mathrm{w} / \mathrm{c}$ ratio. Ordinary Portland cement (OPC) as per standard of ASTM C150 was used to manufacture the specimens of both concretes. Crushed stones obtained from the local market were used as coarse aggregates. They were washed, air dried to SSD, and sieved accordingly to achieve each specified aggregate gradation. Potable water was used for casting and curing of all specimens. All the ingredients of each respective mix were batched accordingly following the proper mixing procedure in an electric operated mixer and were cast accordingly. A total number of 20 cube specimens for NFC and 20 for ordinary concrete $(\mathrm{NC})$ of standard size of $150 \mathrm{~mm} \times 150 \mathrm{~mm} \times 150 \mathrm{~mm}, 20$ cylinders for NFC and NC of standard size of $150 \mathrm{~mm} \times 300 \mathrm{~mm}$ and 20 prisms for NFC and NC of standard size of $100 \mathrm{~mm} \times 100 \mathrm{~mm} \times 500 \mathrm{~mm}$ were cast. The specimens were demoulded after 24 hours of casting and were kept in a curing tank up for 28 days. Before testing the specimens for compressive, splitting tensile, and flexural strength, all the specimens were weighed to determine their unit weight. To determine compressive, splitting tensile, and flexural strength, the cubes, cylinders, and prisms were tested in a universal testing machine (UTM) (see Part I [14] for more UTM testing pictures). The ultimate loads at the failure of specimens were recorded. Five cubes, cylinders, and prisms for NFC and NC were cast from each batch. The ultimate compressive, splitting tensile and flexural strength, and the unit weight of each of the five specimens was measured and the average was used as the final value.

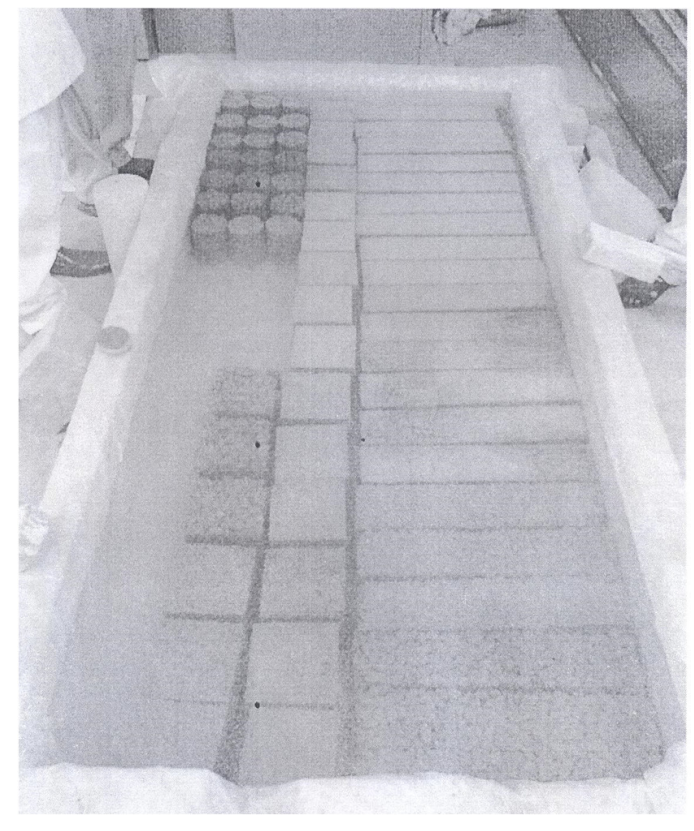

Fig. 1. Specimens under curing

\section{RESULTS AND DISCUSSION}

\section{A. Compressive Strength of NFC}

The results of average compressive strength are presented in Table I.
TABLE I. AVERAGE COMPRESSIVE STRENGTH AND UNIT WEIGHT OF NFC

\begin{tabular}{|c|c|c|c|c|c|}
\hline S.No. & $\begin{array}{c}\text { Aggregate } \\
\text { gradation (mm) }\end{array}$ & $\begin{array}{c}\text { c-a } \\
\text { proportion }\end{array}$ & $\begin{array}{c}\text { w/c } \\
\text { ratio }\end{array}$ & $\begin{array}{c}\text { Compressive } \\
\text { strength (MPa) }\end{array}$ & $\begin{array}{c}\text { Unit weight } \\
\left(\mathbf{k g} / \mathbf{m}^{\mathbf{3}}\right)\end{array}$ \\
\hline 1 & $5-4$ & $1: 6$ & 0.5 & 4.9 & 1687 \\
\hline 2 & $10-4$ & $1: 6$ & 0.5 & 8.2 & 1843 \\
\hline 3 & $20-4$ & $1: 6$ & 0.5 & 9.8 & 1891 \\
\hline 4 & $20-15$ & $1: 6$ & 0.5 & 6.4 & 1735 \\
\hline
\end{tabular}

\section{B. Splitting Tensile Strength of NFC}

The results of average splitting tensile strength are presented in Table II.

TABLE II. AVERAGE SPLITTING TENSILE STRENGTH AND UNIT WEIGHT OF NFC

\begin{tabular}{|c|c|c|c|c|c|}
\hline S.No. & $\begin{array}{c}\text { Aggregate } \\
\text { gradation }(\mathbf{m m})\end{array}$ & $\begin{array}{c}\text { c-a } \\
\text { proportion }\end{array}$ & $\begin{array}{l}\text { w/c } \\
\text { ratio }\end{array}$ & \begin{tabular}{|l} 
Splitting tensile \\
strength (MPa)
\end{tabular} & $\begin{array}{c}\text { Unit weight } \\
\left(\mathrm{kg} / \mathrm{m}^{3}\right)\end{array}$ \\
\hline 1 & $5-4$ & $1: 6$ & 0.5 & 0.6 & 1687 \\
\hline 2 & $10-4$ & $1: 6$ & 0.5 & 1.3 & 1843 \\
\hline 3 & $20-4$ & $1: 6$ & 0.5 & 1.7 & 1891 \\
\hline 4 & $20-15$ & $1: 6$ & 0.5 & 1.1 & 1735 \\
\hline
\end{tabular}

\section{Flexural strength of NFC}

The results of average flexural strength are presented in Table III.

TABLE III. AVERAGE FLEXURAL STRENGTH AND UNIT WEIGHT OF NFC

\begin{tabular}{|c|c|c|c|c|c|}
\hline S.No. & $\begin{array}{c}\text { Aggregate } \\
\text { gradation (mm) }\end{array}$ & $\begin{array}{c}\text { c-a } \\
\text { proportion }\end{array}$ & $\begin{array}{c}\text { w/c } \\
\text { ratio }\end{array}$ & $\begin{array}{c}\text { Flexural } \\
\text { strength }(\mathbf{M P a})\end{array}$ & $\begin{array}{c}\text { Unit weight } \\
\left(\mathbf{k g} / \mathbf{m}^{\mathbf{3}}\right)\end{array}$ \\
\hline 1 & $(5-4)$ & $1: 6$ & 0.5 & 1.2 & 1687 \\
\hline 2 & $(10-4)$ & $1: 6$ & 0.5 & 2.4 & 1843 \\
\hline 3 & $(20-4)$ & $1: 6$ & 0.5 & 3.8 & 1891 \\
\hline 4 & $(20-15)$ & $1: 6$ & 0.5 & 2.1 & 1735 \\
\hline
\end{tabular}

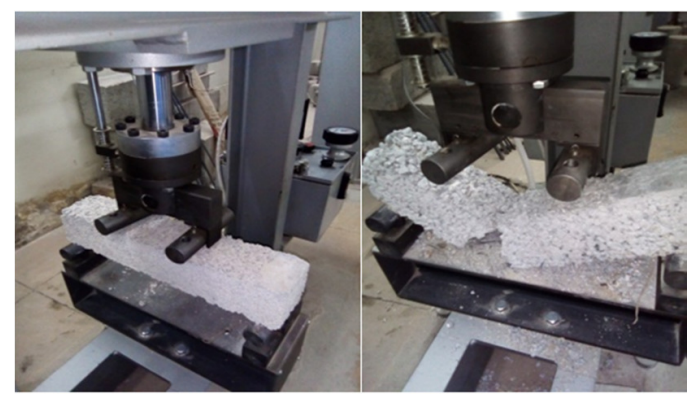

Fig. 2. View of a prism sample before and after testing in UTM

D. Compressive strength of $N C$

The results of average compressive strength are presented in Table IV.

TABLE IV. AVERAGE COMPRESSIVE STRENGTH AND UNIT WEIGHT OF ORDINARY CONCRETE

\begin{tabular}{|c|c|c|c|c|c|}
\hline S.No. & $\begin{array}{c}\text { Aggregate } \\
\text { gradation (mm) }\end{array}$ & $\begin{array}{c}\text { Mix } \\
\text { proportion }\end{array}$ & $\begin{array}{c}\text { w/c } \\
\text { ratio }\end{array}$ & $\begin{array}{c}\text { Compressive } \\
\text { strength (MPa) }\end{array}$ & $\begin{array}{c}\text { Unit weight } \\
\left(\mathbf{k g} / \mathbf{m}^{\mathbf{3}}\right)\end{array}$ \\
\hline 1 & $5-4$ & $1: 2: 4$ & 0.5 & 21.2 & 2339 \\
\hline 2 & $10-4$ & $1: 2: 5$ & 0.5 & 29 & 2366 \\
\hline 3 & $(20-4)$ & $1: 2: 4$ & 0.5 & 30.4 & $2445 \mathrm{z}$ \\
\hline
\end{tabular}




\section{E. Splitting Tensile Strength of NC}

The results of average splitting tensile strength are presented in Table V.

TABLE V. AVERAGE SPLITTING TENSILE STRENGTH AND UNIT WEIGHT OF ORDINARY CONCRETE

\begin{tabular}{|c|c|c|c|c|c|}
\hline S.No. & $\begin{array}{c}\text { Aggregate } \\
\text { gradation } \\
(\mathbf{m m})\end{array}$ & $\begin{array}{c}\mathbf{c - a} \\
\text { proportion }\end{array}$ & $\begin{array}{c}\text { w/c } \\
\text { ratio }\end{array}$ & $\begin{array}{c}\text { Splitting tensile } \\
\text { strength }(\mathbf{M P a})\end{array}$ & $\begin{array}{c}\text { Unit } \\
\text { weight } \\
\left(\mathbf{k g} / \mathbf{m}^{\mathbf{3}} \mathbf{)}\right.\end{array}$ \\
\hline 1 & $5-4$ & $1: 2: 4$ & 0.5 & 2.2 & 2339 \\
\hline 2 & $10-4$ & $1: 2: 4$ & 0.5 & 2.7 & 2366 \\
\hline 3 & $20-4$ & $1: 2: 4$ & 0.5 & 3.4 & 2445 \\
\hline
\end{tabular}

\section{F. Flexural strength of NC}

The results of average compressive strength are presented in Table VI.

TABLE VI. AVERAGE FLEXURAL STRENGTH AND UNIT WEIGHT OF ORDINARY CONCRETE

\begin{tabular}{|c|c|c|c|c|c|}
\hline S.No. & $\begin{array}{c}\text { Aggregate } \\
\text { gradation } \\
(\mathbf{m m})\end{array}$ & $\begin{array}{c}\text { c-a } \\
\text { proportion }\end{array}$ & $\begin{array}{c}\text { w/c } \\
\text { ratio }\end{array}$ & $\begin{array}{c}\text { Flexural } \\
\text { strength } \\
(\mathbf{M P a})\end{array}$ & $\begin{array}{c}\text { Unit } \\
\text { weight } \\
\left(\mathbf{k g} / \mathbf{m}^{\mathbf{3}}\right)\end{array}$ \\
\hline 1 & $5-4$ & $1: 2: 4$ & 0.5 & 3.4 & 2339 \\
\hline 2 & $10-4$ & $1: 2: 4$ & 0.5 & 3.5 & 2366 \\
\hline 3 & $20-4$ & $1: 2: 4$ & 0.5 & 3.8 & 2445 \\
\hline
\end{tabular}

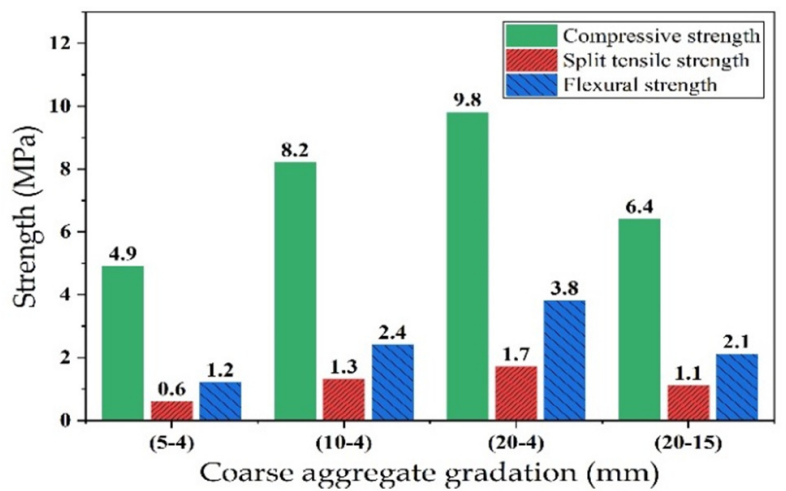

Fig. 3. Compressive, spilitting tensile, and flexural strength of NFC vs. aggregate gradation and $\mathrm{c}-\mathrm{a}$ proportion at $0.5 \mathrm{w} / \mathrm{c}$ ratio

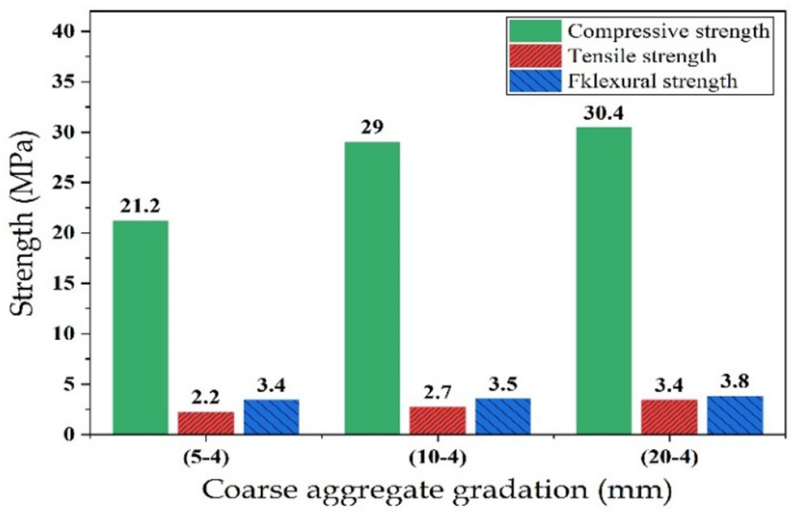

Fig. 4. Compressive, spilitting tensile, and flexural strength of NC vs. aggregate gradation and c-a proportion at $0.5 \mathrm{w} / \mathrm{c}$ ratio
The results reveal the pronounced effect of aggregate gradation and c-a proportion on the compressive strength. Figures 3-4 depict the effect of various course aggregate gradations on the compressive, splitting tensile, and flexural strength of NFC and NC. The significant effect of aggregate gradation is self-evident from the Tables' values and Figures. NFC manufactured with $20 \mathrm{~mm}-4 \mathrm{~mm}$ gradation exhibited the and the NFC with $5 \mathrm{~mm}-4 \mathrm{~mm}$ gradation yielded the lowest compressive, splitting tensile, and flexural strength of the respective group of NFC having the same c-a 1:6 proportion and $0.5 \mathrm{w} / \mathrm{c}$ ratio. On the other hand, $20 \mathrm{~mm}-4 \mathrm{~mm}$ had high compressive, splitting tensile, and flexural strength at 1:2:4 mix proportion and $0.5 \mathrm{w} / \mathrm{c}$ ratio. This infers the significance of aggregate gradation, c-a proportion on the compressive strength, splitting tensile strength, and flexural strength of both NFC and NC.

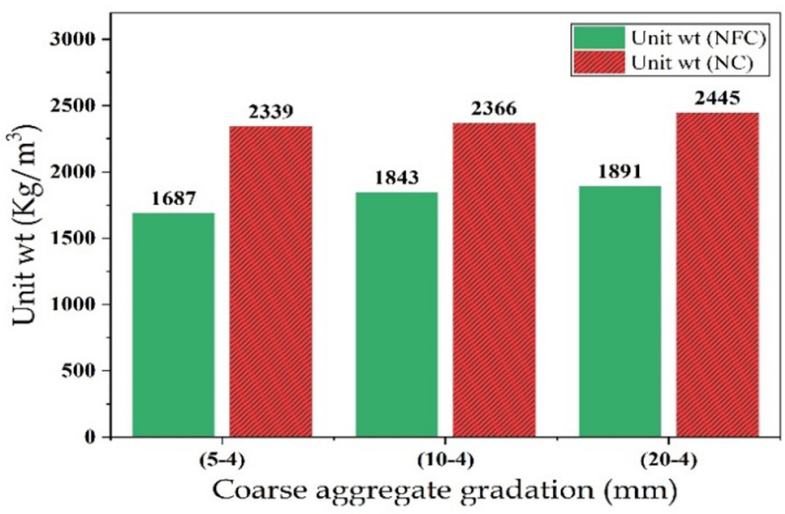

Fig. 5. Comparision between unit weight of NFC and NC

\section{G. Unit Weight}

Table I also shows the values of average unit weight of NFC produced with different aggregate gradation, 1:6 c-a proportion and $0.5 \mathrm{w} / \mathrm{c}$ ratio. The $20 \mathrm{~mm}-4 \mathrm{~mm}$ coarse aggregate gradation had $1891 \mathrm{~kg} / \mathrm{m}^{3}$ and the $5 \mathrm{~mm}-4 \mathrm{~mm}$ coarse aggregate gradation had $1687 \mathrm{~kg} / \mathrm{m}^{3}$ unit weight respectively. The difference between the maximum and minimum values of unit weight is calculated to be only $12.1 \%$ while the difference percentage of NFC and NC is $33 \%$. The unit weight of NFC is slightly affected due to variation in aggregate gradation, c-a proportion and $\mathrm{w} / \mathrm{c}$ ratio but without any significant trend regarding those parameters. This may be observed in Figure 5 where the unit weight values are compared graphically.

\section{CONCLUSION}

- Aggregate gradation significantly affects compressive, splitting tensile, and flexural strength of NFC.

- A difference of $50 \%, 64 \%$ and $68 \%$ was observed between the maximum and minimum compressive, splitting tensile, and flexural strength respectively of NFC due to variation in aggregate gradation and c-a proportion.

- NFC produced with $20 \mathrm{~mm}-4 \mathrm{~mm}$ gradation 1:6 c-a proportion and $0.5 \mathrm{w} / \mathrm{c}$ ratio exhibited the highest compressive strength of $9.8 \mathrm{MPa}$. 
- The minimum compressive, splitting tensile, and flexural strength was found to be $4.9 \mathrm{MPa}, 0.6 \mathrm{MPa}$, and $1.2 \mathrm{MPa}$ in the case of NFC with $5 \mathrm{~mm}-4 \mathrm{~mm}$ aggregate gradation, 1:6 c-a proportion at $0.5 \mathrm{w} / \mathrm{c}$ ratio.

- A difference of $30 \%, 35 \%$ and $10 \%$ was observed between the maximum and minimum compressive, splitting tensile, and flexural strength respectively of $\mathrm{NC}$ due to variation in aggregate gradations.

- NC produced with $20 \mathrm{~mm}-4 \mathrm{~mm}$ gradation mix proportion $1: 2: 4$ at $0.5 \mathrm{w} / \mathrm{c}$ ratio exhibited the highest compressive, splitting tensile, and flexural strength of $30.4 \mathrm{MPa}, 3.4 \mathrm{MPa}$, and $3.8 \mathrm{MPa}$, respectively.

- The minimum compressive, splitting tensile, and flexural strength of $\mathrm{NC}$ was found to be $4.9 \mathrm{MPa}, 0.6 \mathrm{MPa}$, and 1.2MPa when using 5-4mm aggregate gradation, 1:2:4 mix proportion at $0.5 \mathrm{w} / \mathrm{c}$ ratio.

- The unit weight of NFC was found to be marginally affected by the variation in aggregate gradation, c-a proportion and $\mathrm{w} / \mathrm{c}$ ratio.

- The maximum difference between the minimum and maximum unit weight $\left(1687 \mathrm{~kg} / \mathrm{m}^{3}\right.$ and $\left.1891 \mathrm{~kg} / \mathrm{m}^{3}\right)$ was found to be only about $10 \%$.

- The unit weight of NC was found not to be marginally affected by the variation in aggregate gradation, c-a proportion and $\mathrm{w} / \mathrm{c}$ ratio.

- In NC the maximum difference between the minimum and maximum unit weight $\left(2339 \mathrm{~kg} / \mathrm{m}^{3}\right.$ and $\left.2445 \mathrm{~kg} / \mathrm{m}^{3}\right)$ was found to be only about $4 \%$.

Based on the results of the experimental study conducted and the discussions and conclusions made above it may be concluded that while producing NFC, the aggregate gradation, $\mathrm{c}-\mathrm{a}$ proportion, and $\mathrm{w} / \mathrm{c}$ ratio may be chosen appropriately particularly when the compressive strength is the major parameter of consideration. However, to a limited extent, unit weight and apparent texture also depend upon these factors.

\section{ACKNOWLEDGMENT}

The authors are grateful to the Quaid-e-Awam University of Engineering, Science and Technology, Nawabshah for providing the research facilities.

\section{REFERENCES}

[1] M. R. Lomte, "A Review on Study and Analysis of Strength, Permeability and Void Ratio of Pervious Concrete", International Journal for Research in Applied Science \& Engineering Technology, Vol. 6, No. 1, pp. 1717-1720, 2018

[2] S. Ali, S. Kacha, "Correlation among Properties of No Fines Concrete A Review", National Conference on Applications of Nano Technology in Civil Engineering, Vadodara, India, February, 2017

[3] G. Yuvaraj, K. Sundaravadivelu, P. Vembuli, R. Shankaranarayanan, E. Ramya, "A Study on Compressive Strength of Pervious Concrete by Varying the Size of Aggregate", International Journal of Engineering Science and Computing, Vol. 7, No. 4,pp. 10149-10152, 2017

[4] G. Divya, L. Reena, "An Experimental Stduies on Behaviour of Pervious Concrete by Using Addition of Admixtures", International Research Journal of Engineering and Technology, Vol. 4, No. 4, pp. 2366-2370, 2017
[5] U. M. Muthaiyan, "Studies on the properties of pervious fly ash-cement concrete as a pavement material", Cogent Engineering, Vol. 4, No. 1, Article ID, 1318802, pp. 1-17, 2017

[6] K. B. Thombre, A. B. More, S. R. Bhagat, "Investigation of Strength and Workability in No-Fines Concrete", International Journal of Engineering Research \& Technology, Vol. 5, No. 9, pp. 390-393, 2016

[7] K. R. Balsaraf, D. R. Kurhade, K. A. Varpe, N. S. Lohote, D. S. Mehetre, "A Review Paper on No Fines Concrete", International Journal Of Engineering Sciences \& Management”, Vol. 7, No. 1, pp. 293-303, 2017

[8] P. P. Pragnya, K. B. Parikh, A. R. Darji, "A Review on Experimental Investigation of Pervious Concrete Using Alternate Materials", Journal of Emerging Technologies and Innovative Research, Vol. 4, No. 3, pp. 68-70, 2017

[9] C. H. S. Priyanka, "Experimental Analysis on High Strength Pervious Concrete", International Journal of Advances in Mechanical and Civil Engineering, Vol. 4, No. 2, pp. 9-13, 2017

[10] W. T. Kuo, C. C. Liu, D. S. Su, "Use of washed municipal solid waste incinerator bottom ash in pervious concrete", Cement and Concrete Composites, Vol. 37, pp. 328-335, 2013

[11] B. Alam, M. Javed, Q. Ali, N. Ahmad, M. Ibrahim., "Mechanical properties of no-fines bloated slate aggregate concrete for construction application, experimental study", International Journal of Civil And Structural Engineering, Vol. 3, No. 2, 2012

[12] A. Cheng, H. M. Hsu, S. J. Chao, K. L. Lin, "Experimental Study on Properties of Pervious Concrete Made with Recycled Aggregate", International Journal of Pavement Research and Technology, Vol. 4, No. 2, pp. 104-110, 2011

[13] A. K. Jain, J. S. Chouhan, "Effect of shape of aggregate on compressive Strength and permeability properties of pervious concrete", International Journal of Advanced Engineering Research and Studies, Vol. 1, No. 1, pp. 120-126, 2011

[14] Z. A. Tunio, T. Ali, A. S. Buller, F. U. R. Abro, M. A. Abbasi, "Influence of Coarse Aggregate Gradation on the Mechnical Properties of Concrete, Part I: No-Fines Concrete", Engineering, Technology \& Applied Science Research, Vol. 9, No. 5, pp. 4612-4615, 2019

[15] M. Kovac, A. Sicakova, "Pervious Concrete as a Sustainable Solution for Pavements in Urban Areas", Environmental Engineering 10th International Conference, Vilnius, Lithuania, April 27-28, 2017

[16] M. A. Memon, M. A. Bhutto, N. A. Lakho, I. A. Halepoto , A. N. Memon, "Effects of Uncrushed Aggregate on the Mechanical Properties of No-Fines Concrete", Engineering, Technology \& Applied Science Research, Vol. 8, No. 3, pp. 2882-2886, 2018

[17] I. Barisic, M. Galic, I. N. Grubesa, "Pervious concrete mix optimization for sustainable pavement solution", IOP Conference Series: Earth and Environmental Science, Vol. 90, Article ID 012091, 2017

[18] A. Alam, S. Naz, "Experimental Study on Properties of No-fine Concrete", International Journal of Informative \& Futuristic Research, Vol. 2, No. 10, pp. 3687-3694, 2015 